American Journal of Environmental Sciences 5 (1): 41-46, 2009

ISSN $1553-345 \mathrm{X}$

(C) 2009 Science Publications

\title{
Investigation of Cadmium (II) Ions Biosorption onto Pretreated Dried Activated Sludge
}

\author{
${ }^{1}$ R. Darvishi Cheshmeh Soltani, ${ }^{2}$ A. Jonidi Jafari and ${ }^{3}$ Gh. Shams Khorramabadi \\ ${ }^{1}$ Environmental Health Engineer, Tarbiat Modarres University, Tehran, Iran \\ ${ }^{2}$ Department of Environmental Health, School of Public Health, \\ Iran University of Medical Sciences, Tehran, Iran \\ ${ }^{3}$ School of Public Health, Lorestan University of Medical Sciences, Tehran, Iran
}

\begin{abstract}
Problem statement: Heavy metals have been one of hazardous components in industrial effluents that can be damaged on the environment by discharging uncontrolled wastewater. The aims of this investigation were biosorption of $\mathrm{Cd}$ (II) ions onto pretreated dried activated sludge and determination of kinetic and isotherm of biosorption. Approach: Activated sludge was obtained from Tehran municipal wastewater treatment plant. Activated Sludge was dried and used for biosorbtion of $\mathrm{Cd}$ (II) ions from aqueous solution. Dried Activated Sluge (DAS) was pretreated with three different solutions $\left(\mathrm{H}_{2} \mathrm{O}_{2}, \mathrm{NaOH}\right.$ and ethanol). Biosorption capacity of different types of DAS to remove Cd (II) ions was investigated as a function of Cd (II) concentrations at variable initial Cd (II) concentrations between 10 and $500 \mathrm{mg} \mathrm{L}^{-1}$ with a DAS particle size 0.2-0.3 mm using batch biosorption experiments. Results: Biosorption of Cd (II) by Dried Activated Sludge (DAS) was found to perform better than the others after pretreatment with $\mathrm{H}_{2} \mathrm{O}_{2}$. The maximum biosorption capacity was given $256.41,217.39$, 212.77 and $204.08 \mathrm{mg} \mathrm{g}^{-1}$ for the $\mathrm{H}_{2} \mathrm{O}_{2}, \mathrm{NaOH}$; Ethanol pretreated and untreated DAS, respectively. The pseudo-second order kinetic model was found to be more suitable than the pseudo-first order kinetic model to correlate the experimental data for all types of DAS $\left(\mathrm{R}^{2}>0.9\right)$. The Freundlich isotherm was found to fit the experimental data slightly better than the Langmuir isotherm model for all pretreated and untreated DAS $\left(\mathrm{R}^{2}>0.99\right)$. Conclusion: It can be concluded that pretreatment DAS yield higher Cd (II) biosorption capacity, especially DAS that pretreated with $\mathrm{H}_{2} \mathrm{O}_{2}$.
\end{abstract}

Key words: Wastewater, chrome, sorbtion, isotherm, kinetic

\section{INTRODUCTION}

Heavy metal ions present in some industrial effluents have detrimental effects on the environments such as water and soil ${ }^{[1-5]}$. Conventional methods for removal of heavy metals from industrial wastewater such as: chemical precipitation, ion-exchange, adsorption, solvent extraction were found to be ineffective or expensive and require high capital and operating costs, also may result large volumes of sludge causing disposal problems ${ }^{[1,5-10]}$. Therefore, recent researches have been focused on use of nonconventional alternative including different biomaterials such as: waste sludge, algae, yeast and fungal biomass ${ }^{[1,5,6]}$. Biomaterials are environmentalfriendly, cost-effective, highly selective, high biosorption capacity and high efficiency in detoxifying dilute wastewater ${ }^{[1,5,7-9]}$. Biosorption of metal ions is the passive binding of heavy metal ions to biopolymers on the cell wall of organisms. On the other hand, passive binding of heavy metal ions was defined as biosorption and active binding on the cell wall of live organisms defined as bioaccumulation ${ }^{[1,5,10]}$. Dead biomaterial is more applicable than living biomaterial, because living system requires nutrients and maintenance of living biomass is very difficult in high toxicity environment. In addition, dead biomaterials can be easily regenerated and reuse $\mathrm{e}^{[7,8,10]}$. Waste activated sludge as a biomaterial, for removal of heavy metal ions can be used because of low cost and its availability ${ }^{[1,11-15]}$. Activated sludge consists of microbial population such as bacteria and protozoa $^{[1]}$. Bacterial biomass in activated sludge is a natural biosorbent for heavy metal ions because of its negative cell wall charge. Cell wall of bacteria consists of polymeric substances that contain negatively charged functional groups, such as carboxyl, phosphate and

Corresponding Author: Ahmad Jonidi Jafari, Department of Environmental Health, School of Public Health, Iran University of Medical Sciences, Argentina Sq., Alvand St., No. 52, P.O. Box 15875-4199 Tehran, Iran Tel: +989367254535 
sulfate $^{[1,13,16,17]}$. In a few literatures, biosorption of heavy metal ions onto pretreated activated sludge was studied $^{[2]}$. In this study, dried activated sludge was pretreated with different solutions and the kinetic and isotherm models of the biosorption were investigated.

\section{MATERIALS AND METHODS}

Experimental system: Batch system was performed using $250 \mathrm{~mL}$ erlenmayer flask and shaker at $150 \mathrm{rpm}$ at room temperature $\left(25^{\circ} \mathrm{C}\right)$ for $240 \mathrm{~min}$ to achieve sorption equilibrium time for experiments. Cadmium (II) ions (in form of $\left.\mathrm{Cd}\left(\mathrm{NO}_{3}\right)_{2}\right)$ and Dried Activated Sludge (DAS) were added to the flasks to obtain desired concentrations of $\mathrm{Cd}$ (II) $\left(10-500 \mathrm{mg} \mathrm{L}^{-1}\right)$ and DAS $\left(1 \mathrm{gL}^{-1}\right)$ in the solution. In selection experiments the DAS and $\mathrm{Cd}$ (II) concentrations were $1 \mathrm{gL}^{-1}$ and $50 \mathrm{mg} \mathrm{L}^{-1}$, respectively. The $\mathrm{pH}$ was adjusted to 4 in all selective experiments. After shaking, Samples were collected from the erlenmayer flasks for analysis. A control flask, without biosorbent (DAS) with $50 \mathrm{mg} \mathrm{L}^{-1}$ $\mathrm{Cd}$ (II) ions, was used to determine Cd (II) removal in the absence of the biosorbent. The $\mathrm{pH}$ values were adjusted by using $\mathrm{NaOH}$ or $\mathrm{H}_{2} \mathrm{SO}_{4}$ solutions in all experiments. All biosorption experiments were carried out in triplicates to check the precision of results ${ }^{[18-21]}$.

Experimental procedure: Activated sludge was obtained from a municipal wastewater treatment plant in Tehran, Iran. The sludge was ground and pretreated using three different solutions including $\mathrm{H}_{2} \mathrm{O}_{2}, \mathrm{NaOH}$ and ethanol in order to activate the functional groups for binding heavy metal ions ${ }^{[2]}$. Two hundred milliliters of pretreatment solution were mixed with $2 \mathrm{~g}$ of DAS in a $250 \mathrm{~mL}$ erlenmeyer flask and placed on a shaker at $150 \mathrm{rpm}$ for $6 \mathrm{~h}$ for pretreatment ${ }^{[1]}$. Activated sludge was washed with deionized water after pretreatment. Washed activated sludge was dried at $60^{\circ} \mathrm{C}$ until constant weight, reground and sieved by using standard sieve (particle size between 0.2-0.3 mm).

Analytical methods: The withdrawn samples from the erlenmeyer flasks were filtered. Samples were analyzed for $\mathrm{Cd}$ (II) ions concentration by an atomic adsorption spectroscopy (BRAIC-WFX-130) according to method no.3111B from standard methods for the examination of water and wastewater ${ }^{[22]}$.

Adsorption equilibrium: The equilibrium established between adsorbed metal ions on the biosorbent and unabsorbed metal ions in solution can be described by adsorption isotherm models ${ }^{[10]}$. Two different isotherms, the Langmuir and Freundlich were used for describing adsorption equilibrium. The well known equation of the Langmuir isotherm is:

$\mathrm{q}_{\mathrm{eq}}=\mathrm{q}_{\mathrm{m}}\left(\frac{\mathrm{C}_{\mathrm{eq}}}{\mathrm{K}_{\mathrm{d}}+\mathrm{C}_{\mathrm{eq}}}\right)$

Where:

$\mathrm{q}_{\mathrm{eq}}\left(\mathrm{mg} \mathrm{g}^{-1}\right)=$ The amount of biosorbed metal ions per unit weight of biosorbent

$\mathrm{C}_{\mathrm{eq}}\left(\mathrm{mg} \mathrm{L}^{-1}\right)=$ Unbiosorbed metal ions concentration in solution

$\mathrm{Q}_{\mathrm{m}}\left(\mathrm{mg} \mathrm{g}^{-1}\right)=$ The maximum amount of the biosorbent per unit weight of biosorbent to form a monolayer on the surface of biosorbent

$\mathrm{b}\left(\mathrm{Lm} \mathrm{g}^{-1}\right) \quad=$ Related to the affinity of the binding sites

The Freundlich equation is:

$\mathrm{q}_{\mathrm{e}}=\mathrm{K}_{\mathrm{F}} \mathrm{C}_{\mathrm{e}}^{1 / \mathrm{n}}$

Where, $\mathrm{n}$ and $\mathrm{K}_{\mathrm{F}}$ are the Freundlich constants that $\mathrm{n}$ and $\mathrm{K}_{\mathrm{F}}$ are indicators of sorption intensity and sorption capacity, respectively ${ }^{[11,23]}$. The Freundlich model provides a more realistic description of biosorption by organic matter because of different binding sites. However, in most cases, both equations were fitted the experimental data reasonably well ${ }^{[10]}$. The pseudo-first order and pseudo-second order kinetic models have been used In order to evaluate the mechanism of biosorption. The pseudo-first order kinetic equation is:

$\frac{\mathrm{dq}}{\mathrm{dt}}=\mathrm{k}_{1 \mathrm{ads}}\left(\mathrm{q}_{\mathrm{e}}-\mathrm{q}\right)$

Where:

$\mathrm{q}\left(\mathrm{mg} \mathrm{g}^{-1}\right)=$ The amount of adsorbed metal ions on the biosorbent at time $t$

$\mathrm{k}_{1 \mathrm{ads}}\left(\min ^{-1}\right)=$ The rate constant

The linear form of Eq. 4 is:

$\log \left(\mathrm{q}_{\mathrm{e}}-\mathrm{q}\right)=\log \mathrm{q}_{\mathrm{e}} \frac{\mathrm{k}_{\text {lads }}}{2.303} \mathrm{t}$

A straight line of $\log \left(\mathrm{q}_{\mathrm{e}}-\mathrm{q}\right)$ versus time suggests the suitability of pseudo-first order kinetic model. The second-order kinetic equation is:

$\frac{\mathrm{dq}}{\mathrm{dt}}=\mathrm{k}_{2 \mathrm{ads}}\left(\mathrm{q}_{\mathrm{e}}-\mathrm{q}\right)^{2}$ 
where, $\mathrm{k}_{2 \mathrm{ads}}\left(\mathrm{gm} \mathrm{g}^{-1} \mathrm{~min}^{-1}\right)$ is the rate constant. The linear form of Eq. 5 is:

$$
\frac{\mathrm{t}}{\mathrm{q}}=\frac{1}{\mathrm{k}_{\text {2ads }} \mathrm{q}_{\mathrm{e}}{ }^{2}}+\frac{1}{\mathrm{q}_{\mathrm{e}}} \mathrm{t}
$$

If the second-order kinetics be suitable, the plot of $\mathrm{t} / \mathrm{q}$ against $\mathrm{t}$ of Eq. 6 should give a linear form ${ }^{[2,23,24]}$.

\section{RESULTS}

Effect of Cd (II) concentration: Three different types of pretreated DAS were used in this set of experiments. Cadmium (II) ion concentration was $50 \mathrm{mg} \mathrm{L}^{-1}$ in this experiment while the DAS concentration and $\mathrm{pH}$ were constant at $1 \mathrm{gl}^{-1}$ and 4 , respectively. Variations of the $\mathrm{Cd}$ concentration against time are shown in Fig. 1 for different pretreated DAS. Figure 1 shows that biosorbtion of $\mathrm{Cd}$ (II) ion concentrations increased with time and reached equilibrium after $60 \mathrm{~min}$ for different pretreated and untreated DAS. Hence, sorption equilibrium time was given $60 \mathrm{~min}$, approximately. To investigate initial effects of $\mathrm{Cd}$ (II) ion concentration a set of experiments was designed with varied ion concentrations between 10 and $500 \mathrm{mg} \mathrm{L}^{-1}$ while the different pretreated DAS concentration and $\mathrm{pH}$ were constant at $1 \mathrm{gL}^{-1}$ and $\mathrm{pH} 4$, respectively. Figure 2 shows that rate of biosorption (as $\mathrm{mg} \mathrm{g}^{-1}$ ) was increased with increasing concentration of $\mathrm{Cd}$ (II). The equilibrium biosorbed $\mathrm{Cd}$ (II) concentration was given $211.63,131.905,115.52$ and $114.02 \mathrm{mg} \mathrm{g}^{-1}$ for $\mathrm{H}_{2} \mathrm{O}_{2}$, $\mathrm{NaOH}$, Ethanol pretreated and untreated DAS, respectively.

Kinetic studies: Pseudo-first and Pseudo-second order kinetic models were used to correlate the experimental data (Eq. 3 and 4). Experimental data were plotted in form of $\log$ (qe-q) against time in Fig. 3 to evaluate the suitability of the pseudo-first order model and were plotted in form of $\mathrm{t} / \mathrm{q}$ versus time to show the suitability of the Pseudo-second order kinetic model in Fig. 4.

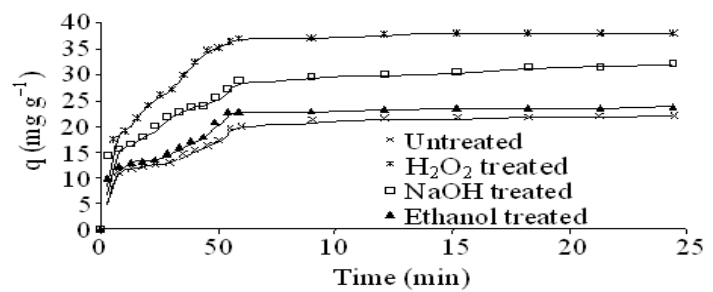

Fig. 1: Variation of biosorbed Cd (II) concentration with time using different types of DAS. $\mathrm{pH}=4$, mixing speed $=150 \mathrm{rpm}$, biosorbent mass $=1 \mathrm{~g} \mathrm{~L}^{-1}$, contact time $=4 \mathrm{~h}$, metal concentration $=50 \mathrm{mg} \mathrm{L}^{-1}$.

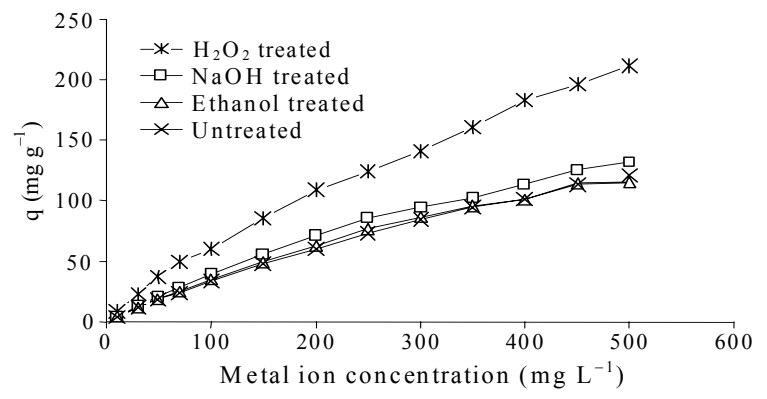

Fig. 2: Variation of biosorbed Cd (II) concentration with initial $\mathrm{Cd}$ (II) ion concentration using different types of DAS. $\mathrm{pH}=4$, mixing speed $=150 \mathrm{rpm}$, biosorbent mass $=1 \mathrm{~g} \mathrm{~L}^{-1}$, contact time $=60 \mathrm{~min}$

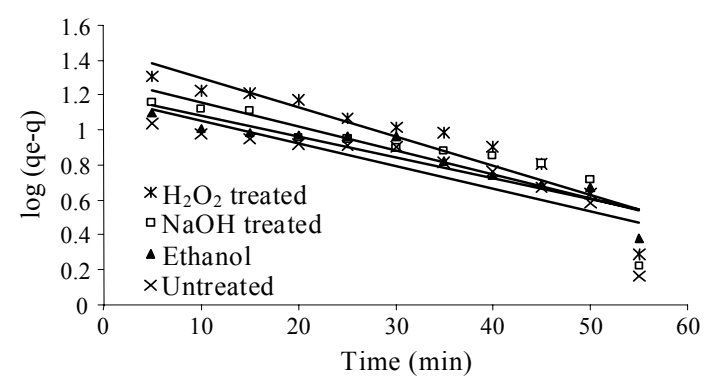

Fig. 3: Pseudo -first order biosorption kinetic of Cd(II) onto different types of DAS. $\mathrm{pH}=4$, mixing speed $=150 \mathrm{rpm}$, biosorbent mass $=1 \mathrm{~g} \mathrm{~L}^{-1}$, contact time $=60 \mathrm{~min}$

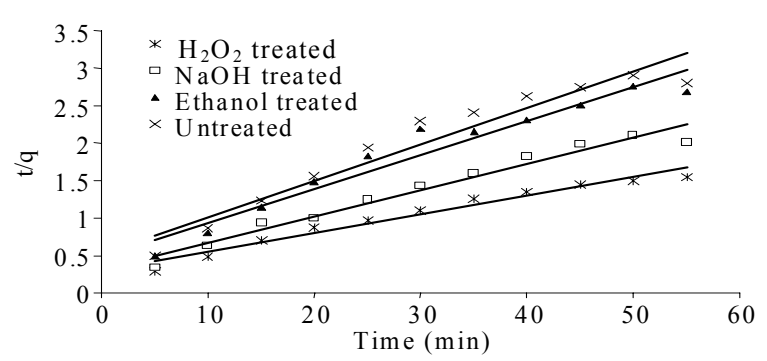

Fig. 4: Pseudo-second order biosorption kinetic of $\mathrm{Cd}$ (II) onto different types of DAS. $\mathrm{pH}=4$, mixing speed $=150 \mathrm{rpm}$, biosorbent mass $=1 \mathrm{~g} \mathrm{~L}^{-1}$, contact time $=60 \mathrm{~min}$

Correlation coefficients of the pseudo-first and pseudosecond order were shown in Table 1.

Adsorption isotherm analysis: The adsorption isotherms were studied with different types of pretreated DAS. Figure 5 and 6 show a plot of linear 
Table 1: Correlation coefficients of Pseudo -first and Pseudo -second order kinetic models

order kinetic models

\begin{tabular}{llll}
\hline & Type of & Pseudo-first order & Pseudo-second order \\
Ion & sludge & $\mathrm{R}^{2}$ & $-\mathrm{R}^{2}$ \\
\hline $\mathrm{Cd}(\mathrm{II})$ & untreated & 0.7581 & 0.9358 \\
& $\mathrm{H}_{2} \mathrm{O}_{2}$ treated & 0.8736 & 0.9657 \\
& $\mathrm{NaOH}^{2}$ treated & 0.7635 & 0.9672 \\
& Ethanol treated & 0.8606 & 0.9446 \\
\hline
\end{tabular}

Langmuir equation as $\mathrm{C}_{\mathrm{e}} / \mathrm{q}_{\mathrm{e}}$ versus $\mathrm{C}_{\mathrm{e}}$ and linear Freundlich equation as $\log \mathrm{q}_{\mathrm{e}}$ versus $\log \mathrm{C}_{\mathrm{e}}$, respectively.

The values of isotherm constants and maximum biosorption capacity $\left(q_{\max }\right)$ were given in Table 2 . The maximum biosorption capacity, $\mathrm{q}_{\max }$, were determined as 256.41, 217.39, 212.77 and $204.08 \mathrm{mg} \mathrm{g}^{-1}$ for $\mathrm{Cd}$ (II) removal with $\mathrm{H}_{2} \mathrm{O}_{2}, \mathrm{NaOH}$, ethanol pretreated and untreated DAS, respectively.

Table 2: Langmuir and Freundlich parameters for biosorption of Cd(II) ion onto different types of DAS.

\begin{tabular}{|c|c|c|c|c|c|c|c|}
\hline \multirow[b]{2}{*}{ Ion } & \multirow[b]{2}{*}{ Type of sludge } & \multicolumn{3}{|c|}{ Langmuir parameters } & \multicolumn{3}{|c|}{ Freundlich parameters } \\
\hline & & $\mathrm{Q}_{\max }$ & $\mathrm{R}^{2}$ & $\mathrm{~b}$ & $\mathrm{~K}_{\mathrm{F}}$ & $\mathrm{n}$ & $\mathrm{R}^{2}$ \\
\hline \multirow[t]{4}{*}{$\mathrm{Cd}(\mathrm{II})$} & untreated & 204.082 & 0.9589 & 0.00320 & 1.148 & 1.262 & 0.9930 \\
\hline & $\mathrm{H}_{2} \mathrm{O}_{2}$ treated & 256.410 & 0.9139 & 0.01000 & 7.290 & 1.680 & 0.9960 \\
\hline & $\mathrm{NaOH}$ treated & 217.390 & 0.9820 & 0.00390 & 1.623 & 1.312 & 0.9943 \\
\hline & Ethanol treated & 212.766 & 0.9796 & 0.00321 & 1.239 & 1.273 & 0.9946 \\
\hline
\end{tabular}

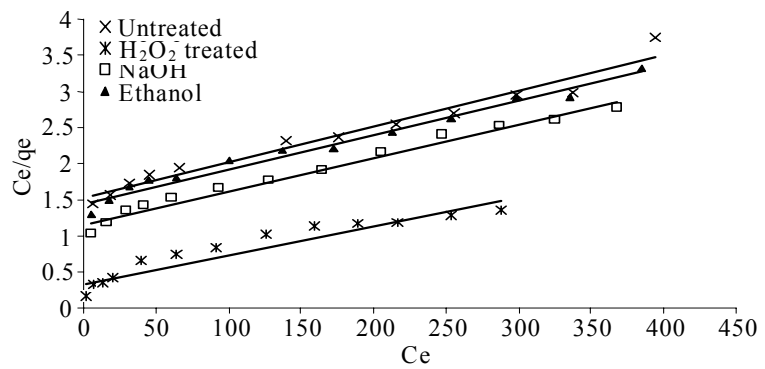

Fig. 5: Langmuir isotherm plot of the biosorption of $\mathrm{Cd}$ (II) onto different types of DAS and untreated DAS. $\mathrm{pH}=4$, mixing speed $=150 \mathrm{rpm}$, variations of $\mathrm{Cd}$ (II) concentration (5-500), biosorbent mass $=1 \quad \mathrm{~g} \mathrm{~L}^{-1}, \quad$ contact time $=60 \mathrm{~min}$

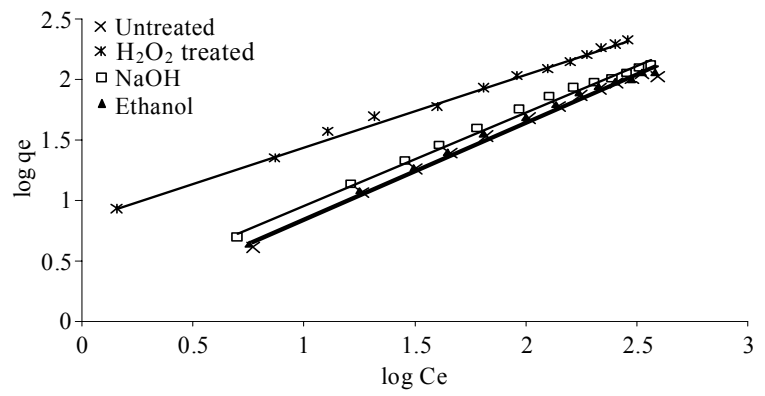

Fig. 6: Freundlich isotherm plot of the biosorption of $\mathrm{Cd}$ (II) onto different types of DAS. $\mathrm{pH}=4$, mixing speed $=150 \mathrm{rpm}$, variations of $\mathrm{Cd}$ (II) concentration (5-500), biosorbent mass $=1 \mathrm{~g} \mathrm{~L}^{-1}$, contact time $=60 \mathrm{~min}$

\section{DISCUSSION}

In the present study, biosorption of $\mathrm{Cd}(\mathrm{II})$ ions has been evaluated as a treatment technology for cadmium removal from industrial effluents. Cadmium removal efficiency at different types of pretreated DAS and in various times was evaluated. The finding shows that duration of time is important to reach equilibrium in reactor which is agreed with some literatures that report indicating higher sorption equilibrium time ${ }^{[1,2,18]}$. For example, Yuncu et al. were shown that biosorped heavy metal ions concentrations increased with time and reached equilibrium after $90 \mathrm{~min}^{[17]}$.

Variations of Cd(II) ion concentration from 10-500 $\mathrm{mg} \mathrm{L}^{-1}$ show that biosorption of $\mathrm{Cd}$ (II) ions increased with increasing concentration of ions. In agreement with this study, Xuejiang et al. ${ }^{[11]}$ and also other researchers have shown that the equilibrium biosorption capacities increased with increase of initial metal ion concentration $^{[1,3,11]}$.

Pseudo-second order kinetic model was found to be more suitable for biosorption of Cd (II) onto all types of pretreated and untreated DAS because of larger correlation coefficients as compared to the other model. Wang et $a l .^{[14]}$ were reported that Pseudo-second order kinetic model represented the data better than the Pseudo-first order model for biosorption of dye by anaerobic sludge. Also in the other studies were shown that Pseudo-second order kinetic model correlated the data better than the Pseudo-first order model for biosorption of different metal ions ${ }^{[5,11,14]}$.

The Langmuir and Freundlich Eq. 1 and 2 were used to model biosorbed metal ions on the biosorbent and unbiosorbed metal ions in solution ${ }^{[10]}$. 
The data in Table 2 show that the Freundlich equation provides a suitable description of the experimental data because of high values of the correlation coefficients. Present investigation indicates that maximum biosorption capacity $\left(\mathrm{q}_{\max }\right)$ is belong to the treated DAS with $\mathrm{H}_{2} \mathrm{O}_{2}$. Yunus Pamukoglu and Fikret Kargi showed that $\mathrm{H}_{2} \mathrm{O}_{2}$ pretreatment solution to be more suitable than the other pretreatment solution because of higher capacity improved for biosorption ${ }^{[2]}$.

The Freundlich model physically provides a more realistic description of adsorption by organic matter because it accounts for different binding sites. But, in most cases, both equations fit the data set reasonably well for the experimental data ${ }^{[10]}$. The other investigators showed that the equilibrium data fitted very well to both Langmuir and Freundlich models for Biosorption of different metal ions ${ }^{[4,11,23,25]}$. In the other researches were shown that biosorption of different metal ions onto biosorbents was fitted by Langmuir ${ }^{[2,5]}$.

\section{CONCLUSION}

The capability of using untreated and pretreated DAS for biosorption of Cd (II) were examined, including equilibration time, effect of initial Cd (II) concentration, kinetic and isotherm studies. Experimental data was shown that most of the Cd (II) ions were sequestered from solution within $60 \mathrm{~min}$ and no considerable increase in biosorbed Cd (II) ions after $60 \mathrm{~min}$ occurred. Initial $\mathrm{Cd}$ (II) ion concentration affected the biosorption as $\mathrm{mg} \mathrm{g}^{-1}$ at constant DAS concentration. The equilibrium adsorption capacities increase with increasing of initial metal ion concentration for all types of DAS. As the Cd (II) ion concentration increased, more binding sites on DAS were occupied by $\mathrm{Cd}(\mathrm{II})$ ions yielding larger biosorbed $\mathrm{Cd}(\mathrm{II})$ as $\mathrm{mg} \mathrm{g}^{-1[1,11]}$. Pseudo-first and Pseudo-second order kinetic models for the biosorption of Cd (II) onto untreated and pretreated DAS were discussed. Pseudosecond order kinetic model correlated the data better than the Pseudo-first order model for biosorption of $\mathrm{Cd}$ (II) ions onto pretreated and untreated DAS. The Freundlich isotherm was found to fit the experimental data slightly better than the Langmuir isotherm. Although the Langmuir isotherm model correlated obtained experimental data reasonably well. Among the three different pretreatment solutions, $\mathrm{H}_{2} \mathrm{O}_{2}$ was found to be more suitable than untreated DAS and the other pretreated DAS $(\mathrm{NaOH}$ and ethanol) that yielding higher Cd (II) biosorption capacity. The maximum biosorption capacity of pretreated DAS for the Cd (II) ions was found $256.41 \mathrm{mg} \mathrm{g}^{-1}$ for $\mathrm{H}_{2} \mathrm{O}_{2}$ pretreated DAS. It can be concluded that pretreatment of DAS yielding higher $\mathrm{Cd}$ (II) biosorption capacity, especially in the case of $\mathrm{H}_{2} \mathrm{O}_{2}$ pretreated DAS.

\section{ACKNOWLEDGEMENT}

The researchers acknowledge the support of Lorestan University of medical sciences.

\section{REFERENCES}

1. Pamukoglu, M.Y. and F. Kargi, 2006. Removal of copper (II) ions from aqueous medium by biosorption onto powdered waste sludge. Process Biochem., 41: 1047-1054. http://cat.inist.fr/ ?aModele $=$ afficheN\&cpsidt $=17631915$.

2. Pamukoglu, M.Y. and F. Kargi, 2006. Batch kinetics and isotherms for biosorption of copper (II) ions onto pre-treated Powdered Waste Sludge (PWS). J. Hazardous Mater., B138: 479-484. http://cat.inist.fr/?aModele=afficheN\&cpsidt $=1839$ 4807.

3. Pamukoglu, M.Y. and F. Kargi, 2007. Biosorption of copper(II) ions onto powdered waste sludgein a completely mixed fed-batch reactor: Estimation of design parameters. Bioresour. Technol., 98: $\quad 1155-1162 . \quad$ http://cat.inist.fr/ ?aModele $=$ afficheN\&cpsidt $=18469059$.

4. Gulnaz, O., S. Saygideger and E. Kusvuran, 2005. Study of $\mathrm{Cu}$ (II) biosorption by dried activated sludge: Effect of physico-chemical environment and kinetics study. J. Hazardous Mater., B120: 193-200. http://cat.inist.fr/ ?aModele $=$ afficheN\&cpsidt $=16695453$.

5. Kargi, F., S. Cikla, 2006. Biosorption of zinc (II) ions onto powdered waste sludge (PWS): Kinetics and isotherms. Enzy. Microbial Technol., 38: 705710 . ?aModele $=$ afficheN\&cpsidt $=17509100$.

6. Tokcaer, E. and U. Yetis, 2006. Pb (II) biosorption using anaerobically digested sludge. J. Hazardous Mater., B137: 1674-1680. http://cat.inist.fr/ ?aModele $=$ afficheN\&cpsidt $=18169051$.

7. Al-Qodah, Z., 2006. Biosorption of heavy metal ions from aqueous solutions by activated sludge. Desalination. 196: 164-176. http://cat.inist.fr/ ?aModele $=$ afficheN\&cpsidt $=18092684$.

8. Jalali, R., H. Ghafourian, Y. Asef, S.J. Davarpanah and S. Sepehr, 2002. Removal and recovery of using nonliving biomass of marine algae. J. Hazardous Mater., B92: 253-262.

9. Utgikara, V., B. Chena, H.H. Tabaka, B.F. Dolloff, and R. Govind, 2000. Treatment of acid mine drainage: I. Equilibrium biosorption of zinc and copper on non-viable activated sludge. Int. Biodeteriorat. Biodegradat., 46: 19-28. http://cat. inist.fr/?aModele=afficheN\&cpsidt=1528837. 
10. Aksu, Z., U. Ac-1kel, E. Kabasakal and S. Tezer, 2002. Equilibrium modeling of individual and simultaneous biosorption of chromium (VI) and nickel (II) onto dried activated sludge. Water Res., 36: 3063-3073. http://cat.inist.fr/ ?aModele $=$ afficheN\&cpsidt $=13751610$.

11. Xuejiang, W., C. Ling, X. Siqing, Z. Jianfu, J.M. Chovelon and N.J. Renault, 2006. Biosorption of $\mathrm{Cu}$ (II) and $\mathrm{Pb}$ (II) from aqueous solutions by dried activated sludge. Mineral. Eng., 19: 968-971. http://cat.inist.fr/?aModele $=$ afficheN\&cpsidt $=1789$ 7858.

12. Hammaini, A., A. Ballester, M.L. Bla'zquez, F. Gonza'lez and J. Muñoz, 2002. Effect of the presence of lead on the biosorption of copper, cadmium and zinc by activated sludge. Hydrometallurgy, 67: 109-116. http://www. ingentaconnect.com/content/els/0304386x/2002/00 000067/00000001/art00157; jsessionid $=2 \mathrm{~d} 4 \mathrm{~g} 8 \mathrm{eq} 47 \mathrm{r}$ 2 ul.alice? format $=$ print.

13. Sag, Y., B. Tatar and T. Kutsal, 2003. Biosorption of $\mathrm{Pb}$ (II) and $\mathrm{Cu}$ (II) by activated sludge in batch and continuous-flow stirred reactors. Bioresour. Technol., 87: 27-33. http://cat.inist.fr/ ?aModele $=$ afficheN\&cpsidt $=14487026$.

14. Wang, Y., Y. Mu, Q.B. Zhao and H.Q. YuIsotherms, 2006. Kinetics and thermodynamics of dye biosorption by anaerobic sludge. Separat. Purificat. Technol., 50: 1-7. http:// cat.inist.fr/?aModele=afficheN\&cpsidt=17799155.

15. Aksu, Z. and F. Gönen, 2004. Biosorption of phenol by immobilized activated sludge in a continuous packed bed: prediction of breakthrough curves. Process Biochem., 39: 599-613. http:// cat.inist.fr/?aModele=afficheN\&cpsidt $=15498465$.

16. Aksu, Z., D. Akpinar, E. Kabasakal and B. Ko“se, 1999. Simultaneous biosorption of phenol and nickel (II) from binary mixtures onto dried aerobic activated sludge. Process Biochem., 35: 301-308. http://www.ingentaconnect.com/content/els/00329 592/1999/00000035/00000003/art00072.
17. Yuncu, B., F.D. Sanin and U. Yetis, 2006. An investigation of heavy metal biosorption in relation to $\mathrm{C} / \mathrm{N}$ ratio of activated sludge. J. Hazardous Mater., B137: 990-997. http://cat.inist.fr/ ?aModele $=$ afficheN\&cpsidt $=18137109$.

18. Aksu, Z. and F. Gonen, 2006. Binary biosorption of phenol and chromium (VI) onto immobilized activated sludge in a packed bed: Prediction of kinetic parameters and breakthrough Carves. Separat. Purificat. Technol., 49: 205-216. http:// cat.inist.fr/?aModele $=$ afficheN\&cpsidt $=17723277$.

19. Diniz, V. and B. Volesky, 2005. Biosorption of La, $\mathrm{Eu}$ and $\mathrm{Yb}$ using sargassum biomass. Water Res., 39: 239-247. DOI: 10.1016/j.watres.2004.09.009.

20. Hamddy, A.A., 2000. Biosorption of heavy metal by marine algae. Curr. Microbiol., 41: 232-238. DOI: $10.1007 / \mathrm{s} 002840010126$.

21. Norton, L., K. Baskaran and T. McKenzie, 2004. Biosorption of zinc from aqueous solutions using biosolids. Adv. Environ. Res., 8: 629-635. DOI: 10.1016/S1093-0191(03)00035-2.

22. Eaton, A.D., L. Clesceri and A.E. Greenbery, 1999. Standard Methods for the Examination of Water and Wastewater. 20th Edn., American Public Health Association, USA., ISBN: 10: 0875532357 , pp: 1325 .

23. Aksu, Z., 2001. Biosorption of reactive dyes by dried activated sludge: Equilibrium and kinetic. Model. Biochem. Eng. J., 7: 79-84. http://cat. inist.fr/?aModele $=$ afficheN\&cpsidt $=870322$.

24. Liu, H.L., B.Y. Chen, Y.W. Lan and Y.C. Cheng, 2004. Biosorption of $\mathrm{Zn}$ (II) and $\mathrm{Cu}$ (II) by the indigenous Thiobacillus thiooxidans. Chem. Eng. J., 97: 195-201. http://cat.inist.fr/ ?aModele $=$ afficheN\&cpsidt $=15494651$.

25. Loukidou, M.X., A.I. Zouboulis, T.D. Karapantsios and K.A. Matis, 2004. Equilibrium and kinetic modeling of chromium (VI) biosorption by Aeromonas caviae. Colloids Surfaces A: Physicochem. Eng. Aspect., 242: 93-104. http:// cat.inist.fr/?aModele $=$ afficheN\&cpsidt $=16011611$. 